\title{
THE EFFECTS OF RESERPINE ON OVULATION AND ON THE CORPUS LUTEUM OF THE GUINEA-PIG
}

\author{
RUTH DEANESLY \\ A.R.C. Institute of Animal Physiology, Babraham, Cambridge
}

(Received 28th October 1965)

\begin{abstract}
Summary. Sixty adult female guinea-pigs were treated with reserpine for a study of its effects on the ovaries and reproductive cycle. In the guinea-pig, as in the rat, it will inhibit ovulation, but whereas reserpine, acting through the hypothalamus and pituitary, is luteotrophic and lactogenic in the rat, in the guinea-pig it is neither, but has an inhibitory action on the development and function of the corpus luteum.

Reserpine does not interfere with ovo-implantation in the guinea-pig but later, at 14 to 15 days pregnant when an embryo is more vulnerable and requires a greater supply of progesterone, reserpine causes abortion.

After reserpine treatment, most follicles were unable to respond by ovulation to purified sheep luteinizing hormone, which will induce ovulation in the normal guinea-pig.

Apart from considerations of dosage, species differences in the reactions of the ovaries to reserpine are probably connected with differences in the hypothalamic-hypophysial neuro-secretory paths.
\end{abstract}

\section{INTRODUCTION}

Extensive studies have been made of the effect of reserpine on the reproductive cycle of the rat. It is generally agreed that it causes an inhibition of the pituitaryovarian axis (Barraclough \& Sawyer, 1955; Tuchmann-Duplessis \& MercierParot, 1956; Kehl, Audibert, Gage \& Amarger, 1956a; Tuchmann-Duplessis, Gershon \& Mercier-Parot, 1957; Barraclough, 1957). Oestrus is suppressed and a prolonged di-oestrus occurs, resembling that of pseudopregnancy and lactation (Barraclough \& Sawyer, 1957, 1959; Mayer, Meunier \& Rouault, 1958; Feyel-Cabanes, 1960; Khazan, Sulman \& Winnik, 1960). It appears that, in rats, reserpine blocks the release of $\mathrm{LH}$, the ovulating gonadotrophin, and permits continued luteotrophic (LTH) secretion by its action on the neurosecretory elements of the hypothalamus. Traumatic deciduomata can be produced in the rat uterus and after 8 days' treatment the mammary gland contains secretion, but there is little lobule-alveolar development unless oestradiol is also given. The corpora lutea are enlarged and active (Mayer $e t$ al., 1958).

Hopkins \& Pincus (1963), experimenting on immature normal and hypophysectomized rats, found that reserpine could inhibit gonadotrophin-induced 
ovulation in a majority of both groups, the hypophysectomized rats being more sensitive. This suggests that reserpine has a direct as well as an indirect action on the ovulatory process. Several workers have commented on the marked loss of weight seen in animals receiving more than the lowest doses of reserpine, but from control experiments it is generally agreed that it is not the digestive disturbance and decrease in food intake which affect the reproductive organs.

In the rat the action of reserpine on ovo-implantation and pregnancy depends on the timing and dosage (Tuchmann-Duplessis \& Mercier-Parot, 1956; Tuchmann-Duplessis et al., 1957). In these experiments, pregnancy was terminated in rats injected daily from the day of mating (Days 1 to 6), but it continued in some females injected from Day 3 to Day 12. Reserpine did not prevent ovo-implantation but it interfered with corpus luteum activity later in pregnancy causing progesterone deficiency and abortions. Exogenous progesterone and oestradiol were, however, ineffective. Rather surprisingly (Tuchmann-Duplessis et al., 1957), it was possible for pregnancy to be maintained in $66 \%$ of the group by prolactin; if injections were begun by Day 4 , the corpora lutea would remain functional.

Mayer \& Meunier (1959) obtained somewhat different results: very few fertilized eggs became implanted if reserpine was given daily from 3 days after the vaginal plug till the 10th day. These eggs, however, remained viable, like those in the mated lactating rat, and could be induced to implant after the 10th day by exogenous oestrogen and progesterone. Reserpine appeared to cause an oestrogen deficiency.

In the adult rabbit reserpine induces milk secretion (Kehl et al., 1956a; Sawyer, 1957), but in the immature, oestrogen with or without progesterone is necessary for this to occur (Meites 1957; Kehl \& Lefranc, 1959; Kehl \& Czyba, 1962; Kanematsu, Hilliard \& Sawyer, 1963). Milk secretion may begin 8 to 15 days from the beginning of reserpine treatment, but it shows individual and seasonal variation (Kehl \& Czyba, 1962).

Prolactin in the rabbit is not luteotrophic as in the rat, and reserpine, though lactogenic, may interfere with ovo-implantation and pregnancy, especially if given for several days just after mating (Kehl et al., 1956b). Arnaud (1963) gave reserpine to pregnant rabbits and found indications that the corpora lutea were regressed or reduced in number, but $0.5 \mathrm{mg}$ reserpine daily from Day 1 had no effect on implantation or pregnancy.

In the immature mouse reserpine will inhibit gonadotrophin-induced ovulation (Purshottam, Mason \& Pincus, 1961) and will reduce growth by causing a lower food intake (Delost \& Pruthière, 1962).

No work has been done on the effects of reserpine on the reproductive cycle of the guinea-pig, which differs from that of both rat and rabbit. Barry and his collaborators have investigated pituitary-hypothalamus relations and the suppression of ovulation in the guinea-pig (see 'Discussion').

The present experiments were designed to study the effects of reserpine not merely on ovulation, but on corpus luteum development and maintenance and the length of the cycle in the guinea-pig, so that a comparison could be made with other laboratory species. 


\section{MATERIAL, METHODS AND ANIMALS}

The reserpine used was 'Serpasil', Ciba, $2.5 \mathrm{mg} / \mathrm{ml}$; this was injected, usually into the neck muscles, $0.1,0.2$ or $0.3 \mathrm{ml}$ being given daily, corresponding to doses of $0.25,0.5$ or $0.75 \mathrm{mg}$. The guinea-pigs varied in body weight from 450 to $1100 \mathrm{~g}$. The lowest reserpine doses seemed not to affect the animals adversely, but two doses of $0.2 \mathrm{ml}$ or similar amounts affected the eyes and caused decrease in food intake, digestive disturbance and loss of weight of 25 to $50 \mathrm{~g}$ in a day. Guinea-pigs commonly recovered from this dose, but most of the experimental animals were killed within a few days of the injections; others, including some that were pregnant, survived and pregnancy could continue uninterrupted. In view of reserpine's toxicity and the normal variation in length of the guinea-pig cycle, the present study is essentially a qualitative one, in which the ovarian response has been studied in detail.

The guinea-pigs in the first experiments were from the stock maintained at the National Institute for Medical Research, London. Later the work was transferred to the A.R.C. Institute of Animal Physiology, Babraham, where guinea-pigs of the same strain were available.

The guinea-pig has a 3- to 4-day oestrous phase in which the vagina is partly or fully open; ovulation occurs spontaneously late in this period, $12 \mathrm{hr}$ after the onset of mating behaviour. The vagina is generally closed or closing on the morning when the plug is found. In previous papers (Rowlands \& Short, 1959; Deanesly, 1960, 1963) this has been recorded as Day 0, and the corresponding terminology is used here for unmated animals. The oestrous phase is recorded as Oe 1, 2, etc., from the day when the vagina first opens. In the unmated female (luteal) Day 1 cannot always be judged precisely, and this is allowed for in the description of experiments. A 16-day cycle would be divided into a 3- or 4-day oestrous period (Oe 1 to 4), a Day 0 about the time of ovulation and Days 1 to 11 or 12 of the luteal phase.

Mean diameters of representative corpora lutea in thirty-five normal and experimental animals were calculated from measurements at right angles through the largest section and counts of serial sections.

The sheep luteinizing hormone LH-S-7 was generously supplied by the National Institute of Health, Bethesda, U.S.A.

\section{Follicles and corpora lutea in the guinea-pig}

In the guinea-pig, follicles grow and ripen continuously (Dempsey, 1937) during most of the 16-day cycle. In the absence of an ovulating stimulus they soon degenerate, the inner granulosa cells showing pycnosis. This type of degeneration can be found in both large and medium-sized follicles.

The cyclic corpora lutea of the guinea-pig reach their full size 5 or 6 days after ovulation (Rowlands \& Short, 1959), and sometimes earlier. Typically, the active functional corpus luteum shows luteal cell mitosis; large mitotic figures stand out conspicuously against a pale background, the cytoplasm losing acidophilic staining capacity during cell division. Mitotic figures, recently described in guinea-pigs by Spies, Gier \& Wheat (1964), have been observed by earlier workers but there has been a tendency to attribute them 
to the vascular elements of the corpus luteum (Schmidt, 1942). Actually, mitoses are rare in the first 2 days after ovulation, during the period of active vascularization, but they can be found later in the cycle (Pl. 2, Fig. 7) and become common in pregnancy from 12 to 30 days post coitum (p.c.) when the corpus luteum is secreting actively. There can be no doubt that the luteal cells with their nuclei enlarge and divide. Mitosis among the luteal cells would account for the variability in their size as compared with the luteal cells of the rabbit. Mitoses similar to those in the guinea-pig have been recorded in the corpora lutea of the Marsupial Setonix by Tyndale-Biscoe (1963) and in the pregnant rat by Bassett (1949).

Regression of the cyclic guinea-pig corpus luteum to a vacuolated but still distinct remnant probably occurs over 1 to 2 days. The essential feature seems to be the disappearance of most of the luteal cells; these lose their staining capacity and only fatty tissue remains, appearing vacuolated in routine sections (Pl. 1, Fig. 1); finally the whole gland contracts to a mesh of mainly vascular and fibrous tissue.

\section{EXPERIMENTAL RESULTS}

\section{The effects of reserpine on ovulation}

Reserpine was given to nineteen females (Table 1) at the end of the luteal phase or during the oestrous period; when it is injected before the pre-ovulation changes have taken place, it inhibits ovulation and the ripening follicles degenerate. On the other hand, if it is given very near to or during vaginal oestrus and the animal is killed 2 to 5 days later, the ovaries usually contain fresh corpora lutea, but compared to normal ones at the same stage of the cycle they are small and in an earlier stage of development. Apparently ovulation is delayed until the effect of the injections has worn off and a new group of follicles has had time to enlarge. This would account for the corpora lutea not being fully luteinized 5 to 8 days after oestrus. A temporary check to pituitary gonadotrophin secretion could also be a factor.

These experiments were mainly to test whether reserpine was luteotrophic in the guinea-pig and caused a prolongation of the cycle. The results were negative. In animals injected before oestrus, the vagina closed at about the normal time, sometimes before the last injection. Two females, not in Table 1,

\section{EXPLANATION OF PLATE 1}

Corpora lutea from normal and reserpine-treated guinea-pigs; $\times 36$.

Frg. 1. Degenerating follicles and a regressed corpus luteum; ovulation inhibited. Table 1, No. 10 .

Fig. 2. Recent corpus luteum, still small on cycle Day 5, with a shrunken corpus luteum from the previous cycle. Table 1 , No. 15 .

Fig. 3. Two small recent corpora Jutea on cycle Day 6, after reserpine. Table 1 , No. 16. Fig. 4. Corpus luteum on cycle Day 9 after reserpine, not fully developed, but with many mitotic figures. Table 2, No. 64 .

FIG. 5. Corpus luteum on cycle Day 6 which showed many dividing cells (PI. 2, Fig. 9a and b). Table 2, No. 50.

Fig. 6. Normal fully developed corpus luteum on Day 4 of cycle; few mitotic figures. 
PLATE 1
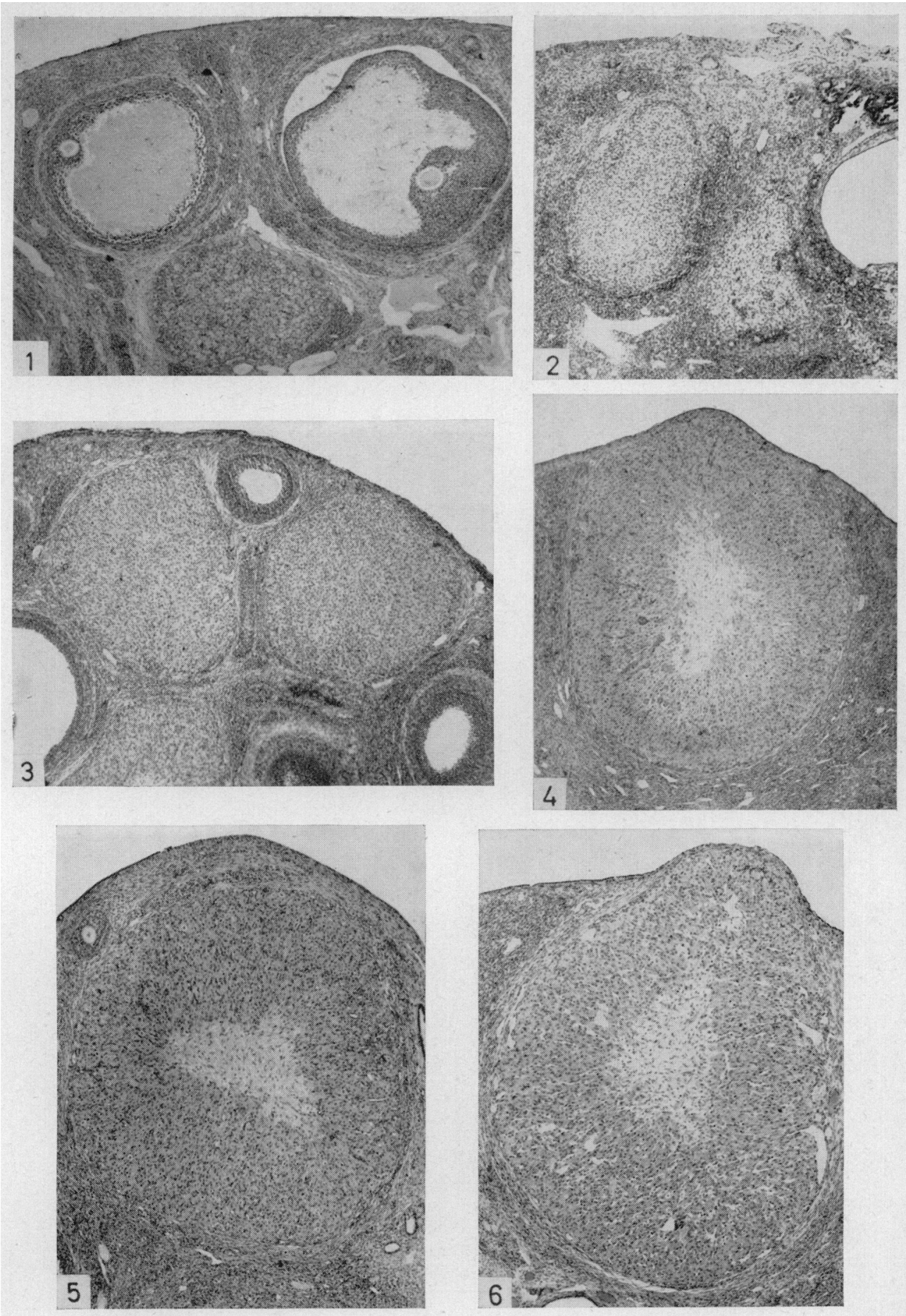

(Facing p. 432) 
PLATE 2
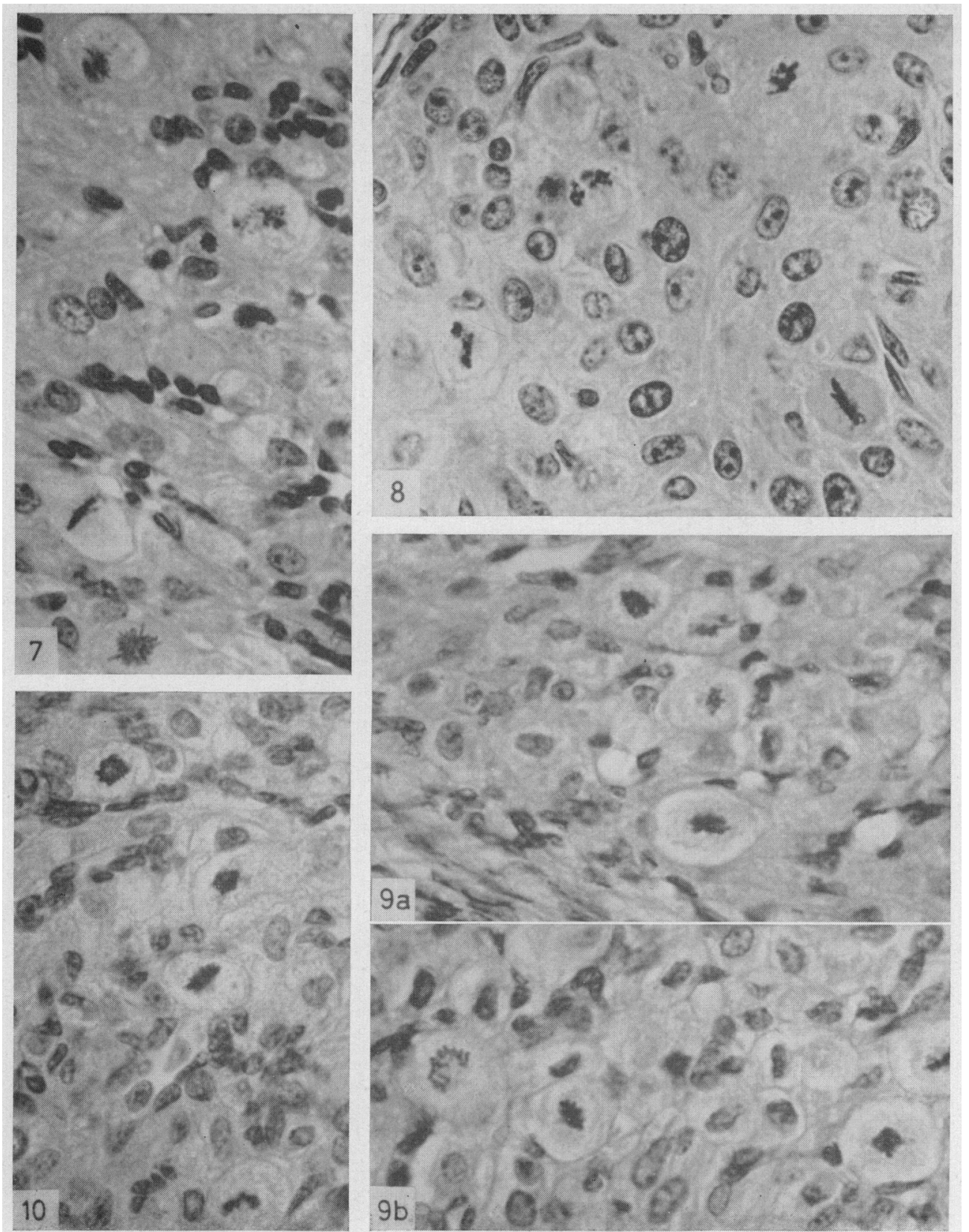

Mitotic figures in luteal cells; $\times 573$.

Fig. 7. Normal cyclic corpus luteum.

lirg. 8. Active cell division 10 days after reserpinc. Table 1 , No. 52.

Fig. 9(a and b). Mitotic figures from a single corpus luteum section. Table 2, No. 50.

Fig. 10. Luteal cell divisions 1 day after reserpine and induced vaginal opening. Table 2, o. 72 . 
had two injections of $0.2 \mathrm{ml}$ reserpine at the end of the cycle and the vagina opened 2 and 4 days after the last injection. The following luteal phase, however, was curtailed, the vagina opening 9 and 8 days after the previous vaginal oestrus. Either ovulation was inhibited altogether or the corpora lutea regressed early. Another animal, No. 52 (Table 1), however, had normal corpora lutea 10 days after the last injection.

In view of Hopkins \& Pincus's (1963) suggestion that reserpine might have a direct as well as an indirect action on the ovary, the ovaries were examined 1 day after two injections of $0.2 \mathrm{ml}$ reserpine. Large and medium-sized normal and degenerating follicles could be seen, such as would be present in an untreated ovary at this stage of the cycle. Although direct ovarian damage by reserpine cannot be excluded, there is no indication from this material that it occurs; the increased follicular regression 3 and 4 days after treatment is probably associated with the inhibition of the ovulating stimulus. The type of pycnotic degeneration found in large and medium follicles is shown in Pl. 1, Fig. 1.

TABLE 1

EFFECT OF RESERPINE $(2.5 \mathrm{mg} / \mathrm{ml})$ ON OVULATION

\begin{tabular}{|c|c|c|c|c|c|}
\hline $\begin{array}{c}\text { Guinea-pig } \\
\text { No. }\end{array}$ & $\begin{array}{l}\text { Dose } \\
(m l)\end{array}$ & $\begin{array}{c}\text { Days } \\
\text { injected }\end{array}$ & $\begin{array}{l}\text { Injections begun: } \\
\text { cycle day }\end{array}$ & $\begin{array}{l}\text { Killed: days from } \\
\text { last injection }\end{array}$ & Result \\
\hline $\begin{array}{r}13 \\
11 \\
8 \\
7 \\
94 \\
95 \\
19 \\
10 \\
9 \\
5 \\
20 \\
21 \\
52 \\
54 \\
17 \\
3 \\
15 \\
16 \\
18\end{array}$ & $\begin{array}{l}0.1 \\
0.2 \\
0.3 \\
0.5 \\
0.2 \\
0.2 \\
0.2 \\
0.3 \\
0.4 \\
0.2 \\
0.2 \\
0.2 \\
0.2 \\
0.2 \\
0.2 \\
0.1 \\
0.1 \\
0.1 \\
0.1\end{array}$ & $\begin{array}{l}4 \\
2 \\
2 \\
1 \\
2 \\
2 \\
2 \\
1 \\
1 \\
3 \\
3 \\
3 \\
2 \\
2 \\
1 \\
5 \\
5 \\
5 \\
5\end{array}$ & $\begin{array}{r}10 \\
10 \\
11 \\
11 \\
12 \\
12 \\
12 \\
12 \\
12 \\
16 \\
\text { Oe } 2 \\
\text { Oe } 3 \\
\text { Oe } 2 \\
\text { Oe } 4 \\
\text { Oe } 1 \\
\text { Oe } 1 \\
\text { Oe } 2 \\
\text { Oe } 2 \\
\text { Oe } 2\end{array}$ & $\begin{array}{r}3 \\
3 \\
3 \\
4 \\
1 \\
1 \\
4 \\
4 \\
4 \\
4 \\
5 \\
4 \\
10 \\
2 \\
4 \\
4 \\
2 \\
3 \\
3\end{array}$ & $\begin{array}{l}\text { No ovulation } \\
\text { Recent corpora lutea }\end{array}$ \\
\hline
\end{tabular}

The effects of reserpine on the early and mid-luteal phase of the cycle

In Table 2, the timing of the injections during the luteal phase and the doses are again somewhat varied. Nine females, however, received $0.2 \mathrm{ml}$ reserpine solution on 2 successive days. Seven were killed 1 to 5 days after the second injection, one died on Day 9 and the last was killed on Day 10 of the cycle. In three females the vagina opened early on Days 6 and 9 and in another, which had five injections of $0.05 \mathrm{ml}$ reserpine solution, the vagina also opened on Day 6; this animal showed patchy cornification of the vaginal epithelium below the mucified layer. The premature vaginal opening indicates an interruption of luteal activity which might have occurred in more animals had they been allowed to survive longer. 
A confirmation of the inhibitory action of reserpine on corpus luteum secretion was obtained by giving four daily doses of $0.1 \mathrm{ml}$ from Day 5 , when the uterus was traumatized by the passage of a thread; 6 days after traumatization no deciduomata had formed in the uterus, indicating a progestagen deficiency.

Histological examination and measurements of the corpora lutea of the treated guinea-pigs (Table 2) showed that, as before, some were smaller and appeared younger than normal ones at a corresponding stage of the cycle.

TABLE 2

EFFECT OF RESERPINE $(2.5 \mathrm{mg} / \mathrm{ml})$ IN THE LUTEAL PHASE OF THE CYCLE

\begin{tabular}{c|c|c|c|c}
\hline $\begin{array}{c}\text { Guinea-pig } \\
\text { No. }\end{array}$ & $\begin{array}{l}\text { Dose } \\
(m l)\end{array}$ & \multicolumn{3}{|c}{ Days of cycle } \\
\cline { 4 - 5 } & & Injections & Vagina open & Killed \\
\hline 50 & $0 \cdot 2$ & $1-2$ & - & 6 \\
59 & $0 \cdot 2$ & $1-2$ & 6 & 7 \\
74 & $0 \cdot 2$ & $1-2$ & - & 3 \\
53 & $0 \cdot 2$ & $2-3$ & 6 & 6 \\
58 & $0 \cdot 2$ & $2-3$ & - & 4 \\
63 & $0 \cdot 2$ & $2-3$ & - & 4 \\
72 & $0 \cdot 05$ & $2-6$ & 6 & 7 \\
57 & $0 \cdot 2$ & 3 & - & 5 \\
62 & $0 \cdot 2$ & $3-4$ & - & 5 \\
64 & $0 \cdot 2$ & $3-4$ & - & 9 \\
61 & $0 \cdot 2$ & $3-4$ & 9 & 10 \\
4 & $0 \cdot 1$ & $5-9$ & - & 12 \\
2 & $0 \cdot 1$ & $7-11$ & - & 14 \\
1 & $0 \cdot 2$ & $8-12$ & - & 16 \\
12 & $0 \cdot 1$ & $8-11$ & - & 14 \\
6 & $0 \cdot 2$ & $8-11$ & - & 14 \\
14 & $0 \cdot 1$ & $9-12$ & - & 15 \\
& & & & \\
\hline
\end{tabular}

The presence, in five animals, of abundant mitotic figures, as many as twenty to thirty-five in a single $7 \mu$ corpus luteum section (Pl. 2, Figs. 9 and 10), suggested renewed pituitary gonadotrophic stimulation after a temporary check. Many of the bigger follicles showed degenerative changes, but others, which had probably enlarged after the end of the treatment, were normal.

In the last four animals in Table 2 all the corpora lutea had regresseda further sign that reserpine in the guinea-pig is not luteotrophic.

A control experiment in which two guinea-pigs were given water only, no food, for 3 days (Days 1 to 3,2 to 4 of the cycle) showed that this deprivation had no effect on the time of the next oestrus or the size of the corpora lutea.

Attempt to induce ovulation with luteinizing hormone $(\mathbf{L H})$ in reserpine-treated females

Table 3 lists seven guinea-pigs each given $200 \mu \mathrm{g}$ LH after being treated with reserpine and two others in which the substances were given together. Sections were cut through one ovary from each animal, both ovaries having previously been examined for fresh ovulations at autopsy. Sheep luteinizing hormone in single subcutaneous doses of 100 or $200 \mu \mathrm{g}$ will induce ovulation in the guineapig (Deanesly \& Perry, 1965; Deanesly, 1966). Only two animals in Table 3 had ruptured follicles, one each in Nos. 92 and 93, in which the LH was given 
2 days after the reserpine instead of 1 day. In No. 91 there were two recent luteinizing follicles with retained eggs. All the ovaries examined contained many large and medium degenerating follicles which apparently could not respond to the ovulation stimulus; only follicles enlarging later, after the reserpine treatment, were able to ovulate in response to the LH.

These animals were all killed late in the cycle and corpora lutea showed various stages of vacuolation. In No. 85, however, the corpora lutea still appeared active and mitotic figures were exceptionally abundant - up to fifty in one corpus luteum section - as though the cells had 'rebounded' 3 days after being checked by reserpine. Previous cycles in this female were of 19 and 17 days which may account for the longer persistence of the corpora lutea.

When reserpine and LH were injected at the same time (Nos. 96 and 97) neither female ovulated although it was near the end of the cycle.

TABLE 3

EFFECT OF LUTEINIZING HORMONE (LH) AND RESERPINE $(2.5 \mathrm{mg} / \mathrm{ml}$ ) ON OVULATION

\begin{tabular}{c|c|c|c|c|l}
\hline \multirow{2}{*}{$\begin{array}{c}\text { Guinea-pig } \\
\text { No. }\end{array}$} & $\begin{array}{c}\text { Dose } \\
(\mathrm{ml})\end{array}$ & \multicolumn{3}{|c|}{ Days of cycle } & \multirow{2}{*}{ Result } \\
\cline { 2 - 5 } & & Injections & LH 200 $\mu \mathrm{g}$ & Killed & \\
\hline 89 & $0 \cdot 1$ & $4-7$ & 8 & 10 & No ovulation \\
84 & $0 \cdot 1$ & $7-9$ & 10 & 11 & No ovulation \\
86 & $0 \cdot 1$ & $7-9$ & 10 & 11 & No ovulation \\
85 & $0 \cdot 1$ & $9-12$ & 13 & 15 & No ovulation \\
91 & $0 \cdot 2$ & $10-11$ & 12 & 13 & No ovulation \\
92 & $0 \cdot 2$ & $10-11$ & 13 & 14 & Ruptured follicle \\
93 & $0 \cdot 2$ & $10-11$ & 13 & 14 & Ruptured follicle \\
96 & $0 \cdot 2$ & 11 & 11 & 12 & No ovulation \\
97 & $0 \cdot 2$ & 11 & 11 & 12 & No ovulation \\
\hline
\end{tabular}

\section{Reserpine and the mammary gland}

Four non-parous, unmated guinea-pigs were given progesterone and oestradiol benzoate to induce proliferation of the mammary gland rudiment. The progesterone, averaging $1 \mathrm{mg}$ daily, was absorbed from subcutaneous tablets and $50 \mu$ g oestradiol was injected in oil every other day. After 10 days, two animals received, additionally, $0.1 \mathrm{ml}$ reserpine daily for 4 days, but no lactogenic effect was seen and the mammary glands were not obviously different from those of the other two in the group.

\section{The effects of reserpine on ovo-implantation and pregnancy}

In the experiments of Mayer \& Meunier (1959) $125 \mu \mathrm{g}$ of reserpine on Day 4 of pregnancy (vaginal plug, Day 1) inhibited implantation on Day 10 in seven out of fifteen rats. When reserpine was given from Days 1 to 9 in a second group only three out of fifteen rats had implanted embryos. If, in addition to reserpine, either progesterone and oestradiol or oestradiol alone was given to the rats, implantation occurred by Day 15 of pregnancy in about a third of the females, showing that some fertilized eggs had remained viable, though unimplanted. 
A similar experiment on guinea-pigs gave different results. Ten guinea-pigs (Table 4) were injected with reserpine, beginning on the day of the vaginal plug or 3 or 4 days later; this was before ovo-implantation, which normally takes place 6 to 7 days after mating. Nine of the guinea-pigs were killed at 10 to 19 days p.c. and eight had implanted embryos, though at 14 days p.c. two of the four embryos were below normal size. The remaining animal gave birth to a normal litter at term as did the last guinea-pig which received $0.2 \mathrm{ml}$ reserpine on Day 7 p.c. Pregnancy corpora lutea at 10 days p.c. in the treated animals looked healthy and showed mitoses, but some were not as large as in the controls, suggesting that development had been temporarily checked.

TABLE 4

OVO-IMPLANTATION AND PREGNANGY IN GUINEA-PIGS RECEIVING RESERPINE $(2.5 \mathrm{mg} / \mathrm{ml})$

\begin{tabular}{c|c|c|c|c}
\hline \multirow{2}{*}{$\begin{array}{c}\text { Guinea-pig } \\
\text { No. }\end{array}$} & \multicolumn{2}{|c|}{ Injections } & $\begin{array}{c}\text { Killed } \\
(\text { days p.c. })\end{array}$ & Implantation sites \\
\cline { 2 - 3 } & Days p.c. & Dose $(\mathrm{ml})$ & & \\
\cline { 2 - 3 } 26 & $0,1,2$ & $0 \cdot 1$ & 10 & 4 \\
28 & $0,1,2$ & $0 \cdot 1$ & 10 & 2 \\
27 & 3 & $0 \cdot 2$ & 18 & 2 \\
24 & $3,4,5$ & $0 \cdot 1$ & 10 & - \\
29 & $3,4,5$ & $0 \cdot 1$ & 10 & 4 \\
40 & 4,5 & $0 \cdot 2$ & 14 & 4 \\
41 & 4,5 & $0 \cdot 2$ & 19 & 2 \\
76 & 4,5 & $0 \cdot 2$ & 10 & 3 \\
77 & 4,5 & $0 \cdot 2$ & 10 & Litter (3) full term \\
60 & 4,5 & $0 \cdot 2$ & - & Litter (2) full term \\
49 & 7 & $0 \cdot 2$ & - & \\
\hline
\end{tabular}

Seven other guinea-pigs, not in Table 4, were given $0.2 \mathrm{ml}$ reserpine on Day 14 or Days 14 and 15 p.c. and three aborted 4 days later; the others received $10 \mathrm{mg}$ progesterone daily in addition to the reserpine, but they also aborted. Previous experiments had shown that embryos are more vulnerable at this critical stage of pregnancy than during implantation (Deanesly, 1960, 1963) and the exogenous progesterone did not compensate for the toxic and other effects of the reserpine.

\section{DISCUSSION}

Reserpine will inhibit ovulation in the guinea-pig, unless the ovulation processes, stimulated by the pituitary, have already begun when it is administered. Unable to ovulate, the ripening follicles degenerate, showing pycnosis of the granulosa cells and sometimes irregular cell divisions of the ova. The reserpine effect is transitory, however, and a fresh group of follicles soon enlarges. The degenerating follicles are similar to those found in normal ovaries, and there is, at present, no evidence that reserpine has a direct as well as an indirect action on follicles. Some of the large follicles 1 day after the reserpine injections (Table 1, Nos. 94 and 95) still appeared normal. Large follicles are essentially unstable structures and if unable to complete their development and rupture they rapidly show degenerative changes in the normal female. 
If reserpine is given after ovulation has already occurred, its effect is to delay the full development of the corpora lutea. In females killed 1 to 4 days after reserpine, most corpora lutea had a mean diameter of about $1 \mathrm{~mm}$ instead of 1.3 or $1.4 \mathrm{~mm}$. The arrangement and appearance of the luteal cells was characteristic of developing rather than of fully-formed corpora lutea. In some animals, 3 or 4 days after reserpine, mitotic figures were exceptionally abundant in the corpora lutea (over thirty in a $7 \mu$ corpus luteum section), perhaps due to a return of gonadotrophic stimulation after a temporary cessation. In earlier experiments (Deanesly \& Perry, 1965) on hysterectomized guinea-pigs it was found that reserpine would induce a transitory vaginal opening, indicating a check to luteal activity.

In pregnant guinea-pigs, the effects of reserpine depended on whether or not functional corpora lutea were necessary at the stage of pregnancy when reserpine was given. Ovo-implantation was not affected by reserpine, but at the 14- to 15-day stage pregnancy was terminated by similar injections. There was evidence that reserpine interfered with corpus luteum activity and the results on pregnant females are comparable to those of Tuchmann-Duplessis et al. (1957) on the rat. Mayer \& Meunier (1959), however, did not observe corpus luteum regression in their experiments; they describe mammary gland development in reserpine-treated rats, which was not seen in guinea-pigs.

Reserpine presumably inhibits ovulation through its action on the secretion or utilization by the follicles both of endogenous and exogenous LH. Mazzuca \& Barry (1963), Barry, Dautrevaux, Lefranc \& Fourlinnie (1963) and Léonardelli \& Barry (1964) have studied the effects of electrolytic lesions of the latero-dorsal hypothalamic nucleus which they believe regulates LH secretion in the guinea-pig. Ovulation can be inhibited by destruction of the acidophil neuro-secretory cells of this area, without damage to 'the classic neurosecretory path', the median hypothalamic area. The differences in the responses to reserpine between the rat and the guinea-pig presumably relate to the hypothalamic-hypophysial axis (Barry et al., 1963) as well as to differences in the release of the hormone maintaining the corpus luteum. Neither reserpine nor oestrogens stimulate or release pituitary luteotrophins in the guinea-pig as they do in the rat.

\section{ACKNOWLEDGMENT}

The author is indebted to the Medical Research Council for support.

\section{REFERENCES}

ARnaud, G. (1963) Nouvelles recherches concernant l'influence de la réserpine sur la gestation de la lapine. C.r. Seanc. Soc. Biol. 157, 1585.

BARRACLOUGH, C. A. (1957) Induction of pseudo-pregnancy in the rat by reserpine and chlorpromazine. (Abstract). Anat. Rec. 127, 262.

BarRaclough, C. A. \& SAWYER, C. H. (1955) Inhibition of the release of pituitary ovulating hormone in the rat by morphine. Endocrinology, 57, 329.

Barraclough, C. A. \& SawYer, C. H. (1957) Blockade of the release of pituitary ovulating hormone in the rat by chlorpromazine and reserpine; possible mechanisms of action. Endocrinology, 61, 341 . 
BARRAclough, C. A. \& SAWYeR, G. H. (1959) Induction of pseudopregnancy in the rat by reserpine and chlorpromazine. Endocrinology, 65, 563.

Barry, J., Dautrevaux, M., Lefranc, G. \& Fourlinnie, C. (1963) Recherches préliminaires sur la topographie du facteur hypothalamique contrôlant la fonction gonadostimulante B préhypophysaire chez le cobaye. C.r. hébd. Séanc. Acad. Sci., Paris, 257, 4217.

BassetT, D. L. (1949) The lutein cell population and mitotic activity in the corpus luteum of pregnancy in the albino rat. Anat. Rec. 103, 597.

DeANesLY, R. (1960) Implantation and early pregnancy in ovariectomized guinea-pigs. $\mathcal{F}$. Reprod. Fert. 1, 242.

Deanesly, R. (1963) Early embryonic growth and progestagen function in ovariectomized guinea-pigs. 7. Reprod. Fert. 6, 143.

DeanesLy, R. (1966) The effects of purified sheep luteinizing hormone on the guinea-pig ovary. 7. Reprod. Fert. 11, 303.

Deanesly, R. \& PERRY, J. S. (1965) Corpus luteum control in hysterectomized guinea-pigs. J. Endocr. 32, 153.

Delost, P. \& Pruthiz̀re, N. (1962) Réserpine et croissance. F. Physiol., Paris, 54, 322.

Dempsey, E. W. (1937) Follicular growth rate and ovulation after various experimental procedures. Am. J. Physiol. 120, 126.

Feyel-Cabanes, T. (1960) Modalités d'action de quelques dérivés de la réserpine sur le corps jaune cyclique de la ratte. Annls Endocr. 21, 217.

Hopknss, T. F. \& Pincus, G. (1963) Effect of reserpine on gonadotrophin-induced ovulation in immature rats. Endocrinology, 73, 775.

Kanematsu, S., Hilliard, J. \& SaWyer, C. H. (1963) Effect of reserpine on pituitary prolactin content and its hypothalamic site of action in the rabbit. Acta endocr., Copenh. 44, 467.

Kehl, R., Audibert, A., Gage, C. \& AmargrR, J. (1956a) Influence expérimentale de la réserpine sur l'activité hypophysogénitale. C.r. Séanc. Soc. Biol. 150, 981.

Kehl, R., Audibert, A., Gage, C. \& Amarger, J. (1956b) Action de la réserpine à différentes périodes de la gestation chez la lapine. C.r. Séanc. Soc. Biol. 150, 2196.

Kent, R. \& CzYBA, J. G. (1962) Sur l'action galactogène de la réserpine chez la lapine. F. Physiol., Paris, 54, 356.

KeHL, R. \& Lefranc, G. (1959) Conditions nécessaires à l'action galactogène de la réserpine, chez la lapine impubère. C.r. Séanc. Soc. Biol. 153, 1319.

Khazan, N., Sulman, F. G. \& WinniK, H. Z. (1960) Effect of reserpine on pituitary-gonadal axis. Proc. Soc. exp. Biol. Med. 105, 201.

LÉnARdelli, J. \& BarRY, J. (1964) Modifications du cycle oestral observées chez le cobaye après lésions stéréotaxiques de l'hypothalamus. C.r. Séanc. Soc. Biol. 158, 1630.

Mayer, G. \& Meunier, J. M. (1959) Réserpine et progestation chez la ratte. Survie des oeufs en phase latente et ovo-implantations normales ou retardées, provoquées par l'oestrogène. C.r. hébd. Séanc. Acad. Sci., Paris, 248, 3355.

Mayer, G., Meunier, J. M. \& Rouault, J. (1958) Etat hormonal provoqué chez la ratte par l'administration de réserpine. Action de l'oestrogène. C.r. hébd. Séanc. Acad. Sci., Paris, 247, 524.

Mazzuca, M. \& Barry, J. (1963) Suppression de l'ovulation chez le cobaye par lésion électrolytique bilatérale du noyau hypothalamique latéro-dorsal interstitiel. C.r. Séanc. Soc. Biol. 157, 119.

Merres, J. (1957) Induction of Iactation in rabbits with reserpine. Proc. Soc. exp. Biol. Med. 96, 728.

Purshottam, N., Mason, M. M. \& Pincus, G. (1961) Induced ovulation in the mouse and the measurement of its inhibition. Fert. Steril. 12, 346.

Rowl.ANDS, I. W. \& SHort, R. J. (1959) The progesterone content of the guinea-pig corpus luteum during the reproductive cycle and after hysterectomy. $\mathcal{~ F . ~ E n d o c r . ~ 1 9 , ~} 81$.

SAWYER, G. H. (1957) Induction of lactation in the rabbit with reserpine. (Abstract). Anat. Rec. 127, 362.

Schmid, I. G. (1942) Mitotic proliferation in the ovary of the normal mature guinea-pig treated with colchicine. Am. F. Anat. 71, 245.

SPIEs, H. G., GIER, H. T. \& WhEAT, J. D. (1964) Ovarian changes in hormone treated hysterectomized and cycling guinea pigs. Trans. Kans. Acad. Sci. 67, 517.

Tuchmann-Duplessis, H., Gershon, R. \& Mercier-Parot, L. (1957) Troubles de la gestation chez la ratte provoquées par la réserpine et essais d'hormonothérapie compensatrice. $\mathcal{F}$. Physiol., Paris, 49, 1007.

Tuchmann-Duplessis, H. \& Mercier-Parot, L. (1956) Action de la réserpine sur l'appareil génital de la ratte adulte. C.r. hébd. Séanc. Acad. Sci., Paris, 242, 1233.

TyNDAle-Biscoe, G. H. (1963) The role of the corpus luteum in the delayed implantation of marsupials. Delayed Implantation, pp. 15-28. Ed. A. C. Enders. University of Chicago Press. 